\title{
ANALISIS SENYAWA HALUSINOGEN DALAM MINUMAN MAGIC MUSHROOM (Psilocybin baeocystis) YANG BEREDAR DI KAWASAN KUTA-BALI
}

\author{
N. M. Suaniti*, O. Ratnayani, S. A. Sari \\ Jurusan Kimia FMIPA Universitas Udayana, Bukit Jimbaran, Bali \\ *Email: madesuaniti@unud.ac.id
}

\begin{abstract}
ABSTRAK
Sampel minuman magic mushroom telah diekstraksi dengan metode SPE menggunakan pelarut metanol dan dianalisis dengan kromatografi gas-spektrofotometer massa (GC-MS). Hal ini menghasilkan tiga puncak spektrum dengan spektrum dominan yang diidentifikasi sebagai senyawa halusinogen psilosin dengan waktu retensi 21,08 menit dan kelimpahan sebesar $80,53 \%$. Melalui penelitian ini diperoleh metode ekstraksi senyawa halusinogen psilosin dalam minuman magic mushroom dan deteksi secara optimal dengan kromatografi gas, sehingga dapat diterapkan dalam analisis kasus penyalahgunaan magic mushroom yang beredar di Kawasan Kuta-Bali.
\end{abstract}

Kata kunci: magic mushroom, halusinogen, psilosin, pilosibin, SPE, GC-MS, forensik.

\begin{abstract}
Magic mushrooms beverage samples have been extracted by SPE method using methanol and analyzed by gas chromatography-mass spectrophotometer (GC-MS). This results is a spectrum with three peaks were identified as the dominant spectrum of hallucinogenic compounds psilosin with retention time 20.08 minutes and an abundance of $80.53 \%$. Through this study were obtained extraction method psilosin hallucinogenic compounds in beverages magic mushrooms and optimal detection with gas chromatography, so that the analysis can be applied in the case of misuse of magic mushrooms in circulation in the area of Kuta-Bali.
\end{abstract}

Keywords: magic mushroom, halusinogenic, psilocybe, psilocybin, SPE, GC-MS, forensic.

\section{PENDAHULUAN}

Magic mushroom atau jamur ajaib adalah kelompok jamur halusinogen yang termasuk dalam genus Psilocybe. Jamur ini mempunyai tudung kepala botak dan hidup di daerah lembab seperti jamur pada umumnya, di sekitar tinja hewan herbivora (sapi, kuda, kerbau, dan lain-lain) yang telah diproses oleh bakteri (Barry, 2005). Jamur ini telah lama digunakan oleh bangsa asli Mesoamerika dalam pertemuan agama, ritual ketuhanan, dan penyembuhan. Pada masa modern seperti sekarang ini, konsumsi magic mushroom dilakukan dengan lebih kreatif, dengan mencampurkannya dalam makanan maupun minuman (Matsushima, et al., 2009). Hingga saat ini, senyawa psilocybin yang terkandung didalamnya telah disintesis dan digunakan dalam kepentingan ilmu kedokteran sebagai obat penghilang rasa sakit dan terapi penyembuhan kanker akut.
Magic mushroom dapat memberikan efek halusinasi karena mengandung senyawa psilosibin dan psilosin yang merupakan senyawa kimia halusinogen (Hofmann, 1958). Efek halusinasi yang ditimbulkan oleh magic mushroom berbeda-beda pada tiap penggunanya yang dipengaruhi oleh jenis kelamin, usia, aktivitas, dosis, cara pajanan, perasaan pengguna, postur tubuh dan kemampuan metabolisme tiap individu. Faktor-faktor tersebut juga mempengaruhi secara kuantitatif kadar senyawa psilosibin dan psilosin yang dapat dianalisis di dalam tubuh pasca konsumsinya (Leary, 2000). Penelitian yang dilakukan psikolog Amerika, Timothy Leary, mengenai efek dari obat psikedelik yang terangkum dalam Harvard Psilocybin Project menjelaskan bahwa, efek dari senyawa psilosibin dan psilosin tersebut terlihat 10-40 menit setelah konsumsi, dan berakhir 2-6 jam tergantung pada faktor yang telah disebutkan sebelumnya. Dalam waktu 24 jam, sekitar $65 \%$ dari psilosibin yang diserap 
diekskresikan bersama urin, dan $15-20 \%$ lebih diekskresikan dalam empedu dan feses. Meskipun sebagian besar psilosibin yang tersisa hilang dengan cara tersebut dalam waktu 8 jam, namun beberapa metabolit psilosin masih terdeteksi dalam urin setelah 7 hari (Leary, 2000).

Ada banyak metode yang tersedia dalam literatur untuk analisis psilosibin dan psilosin dalam spesimen biologi. Ekstraksi sampel magic mushroom murni yang paling umum adalah menggunakan teknik maserasi dengan metanol dengan pertimbangan sifat polar dari senyawa psilosibin dan psilosin itu sendiri (Tiscione, et al., 2006). Ekstraksi untuk analisis kuantitatif senyawa psilosibin dan psilosin dari bubuk kering jamur dilakukan dengan perendaman selama 12 jam dalam metanol merupakan metode dengan hasil yang paling optimal (Beug dan Bigwood, 1981).

Eksposur Magic mushroom dapat dilakukan dengan berbagai cara, salah satunya melalui pajanan minuman. Albert, et al. (2011) melaporkan bahwa tes presumtif untuk mengetahui keberadaan senyawa halusinogen yang terkandung dalam Magic mushroom adalah dengan menggunakan uji warna Marquist dan Weber. Perubahan warna menjadi oranye pada Tes Marquist menandakan keberadaan Psilocybin sedangkan perubahan warna menjadi hijau kecoklatan menandakan positif psilocin. Uji positif Psilocybin dan psilocin pada tes Weber adalah perubahan warna menjadi oranye kemerahan, kemudian pemastian dengan tetesan $\mathrm{HCl}$ yang menunjukkan perubahan warna menjadi biru kehijauan. Metode yang digunakan dalam analisis Magic mushroom adalah dengan Solid Phase Extraction (SPE) yang kemudian dilanjutkan dengan uji pemastian instrumentasi menggunakan GC-MS (Albert, et al., 2011).

Berdasarkan latar belakang di atas diperoleh gambaran dimensi permasalahan yang begitu luas, namun menyadari adanya keterbatasan waktu dan kemampuan, maka penulis memandang perlu memberi batasan masalah secara jelas dan terfokus pada ekstraksi senyawa halusinogen psilosin dalam minuman yang mengandung magic mushroom yang beredar di kawasan Kuta-Bali dan mendeteksi keberadaannya menggunakan GC-MS.
Selanjutnya hasil analisis yang didapat dalam bentuk kromatogram atau pemisahan dan fragmen ion diinterpretasikan secara kimia.

\section{MATERI DAN METODE}

\section{Bahan}

Bahan-bahan yang digunakan dalam penelitian ini yaitu Magic mushroom, larutan fast blue $B B$, pereaksi marquis, asam klorida, asam asetat glasial, larutan formaldehid, metanol, air distilat, buffer Fosfat $100 \mathrm{mM}$ (pH 6), amonium hidroksida 4\%, dan etil asetat.

\section{Peralatan}

Alat-alat yang digunakan adalah catridge, peralatan gelas yang biasa digunakan dalam laboratorium dan GC-MS.

\section{Cara Kerja \\ Ekstraksi Magic Mushroom}

Beberapa spesimen jamur kering dihaluskan dengan mortar dan di masukkan dalam tabung reaksi. Kemudian di tambahkan 1$2 \mathrm{~mL}$ metanol dan di kocok selama 5 menit.

\section{Ekstraksi Minuman Magic Mushroom}

Minuman magic mushroom diekstraksi menggunakan metode Solid Phase Extraction (SPE) dengan pelarut metanol. Sampel minuman ditambahkan $3 \mathrm{~mL}$ larutan buffer Fosfat $100 \mathrm{mM}$ $\mathrm{pH}$ 6. Kemudian diaduk hingga tercampur homogen menggunakan vortex. Kolom SPE (UCT, Inc) dikondisikan bersih dengan cara dicuci menggunakan $1 \times 3 \mathrm{~mL}$ metanol, 1 × 3 $\mathrm{mL}$ air distilat, dan $1 \times 3 \mathrm{~mL}$ larutan buffer Fosfat $100 \mathrm{mM}$ (pH 6). Sampel minuman yang telah mengalami perlakuan awal kemudian dimasukkan ke dalam kolom ekstraksi yang telah berisi ekstralut. Sampel minuman tersebut dimasukkan ke dalam kolom secara perlahan sekitar $2 \mathrm{~mL} / m e n i t$. Kemudian dicuci kembali menggunakan air distilat dan metanol masingmasing $3 \mathrm{~mL}$. Selanjutnya sampel dielusi dengan $3 \mathrm{~mL}$ etil asetat $2 \%$ yang mengandung amonium hidroksida $2 \%$ untuk analisis senyawa psilosin, sedangkan untuk analisis senyawa psilosibin, sampel minuman di elusi dengan $3 \mathrm{~mL}$ metanol yang mengandung amonium hidroksida $4 \%$. Eluat yang tertampung diuapkan sampai kering 
secara terpisah pada suhu $<40^{\circ} \mathrm{C}$. Selanjutnya, eluat kering ditambahkan $100 \mu \mathrm{L}$ metanol untuk kemudian dianalisis dengan GC-MS.

\section{Analisis dengan GC-MS}

Sebanyak $1 \mu \mathrm{L}$ ekstrak metanol Magic mushroom dan minuman Magic mushroom dianalisis menggunakan GC-MS Tandem MS Agilent 19091S-433 yang dioperasikan dengan kolom kaca panjang Silika fused, chemically bonded, kolom kapiler $30 \mu$, diameter $250 \mu \mathrm{m}$ dengan fasa diam CP-Sil 5CB pada suhu oven terprogram antara $70-270^{\circ} \mathrm{C}$ ditingkatkan $10^{\circ} \mathrm{C} /$ menit, gas pembawa Helium bertekanan $8,80 \mathrm{psi}$, total laju $23,6 \mathrm{~mL} / \mathrm{menit}$ dan split ratio Splitless 20:1.

\section{HASIL DAN PEMBAHASAN}

Data kromatogram dalam minuman Magic Mushroom menggunakan kromatografi gas diperoleh 3 (tiga) puncak senyawa dengan kelimpahan dominan ditunjukkan oleh senyawa puncak pertama. Data kromatogram tersebut menentukan pola fragmentasi dari masingmasing senyawa kemudian pola fragmentasi dan puncak dasar yang khas dapat dijadikan acuan untuk menentukan struktur dari masing-masing senyawa. Gambar 1 menunjukkan hasil kromatogram minuman Magic Mushroom.

Berdasarkan data kromatogram, puncak paling dominan terdapat pada puncak pertama. Hasil analisis menggunakan GC-MS menunjukkan bahwa senyawa kimia yang terkandung dominan Psilosin.



\section{Gambar 1. Hasil kromatogram minuman Magic Mushroom}



\section{Gambar 2. Spektogram fragmentasi massa senyawa puncak 1}

Gambar 2 menunjukkan spektogram fragmentasi massa senyawa psilosin pada puncak 1 dengan kelimpahan $80.53 \%$.

Puncak 1 dengan waktu retensi 20,08 menit dan kelimpahan sebesar 80,53\% menghasilkan spektrum massa yang menunjukkan adanya ion molekul $\left(\mathrm{M}^{+}\right)$pada $\mathrm{m} / \mathrm{z}$ 281 dan juga sebagai puncak dasar spektrum massa puncak 1. Ion molekul $\left(\mathrm{M}^{+}\right)$pada $\mathrm{m} / \mathrm{z} 281$ menunjukkan bahwa senyawa pada puncak 1 memiliki berat molekul sebesar 281. Berat molekul puncak 1 yang ganjil menunjukkan bahwa senyawa pada puncak 1 mengandung komponen atom $\mathrm{N}$ atau jumlah atom $\mathrm{N}$ genap. Rumus molekul yang paling mungkin berdasarkan Tabel Beynon adalah $\mathrm{C}_{12} \mathrm{H}_{16} \mathrm{~N}_{2} \mathrm{O}$ dan berdasarkan pendekatan database dengan melihat berat molekul, puncak 1 adalah senyawa Psilosin.

Kromatogram minuman Magic Mushroom menunjukkan hasil yang sangat dominan terhadap senyawa halusinogen psilosin, yaitu dengan kelimpahan 80,53\%. Bila dibandingkan dengan kromatogram Magic Mushroom alami sebagai pedoman, waktu retensi yang dibutuhkan untuk deteksi senyawa psilosin mempunyai kesamaan yang spesifik yaitu pada menit ke 21.08. Hal ini menunjukkan bahwa minuman Magic Mushroom yang beredar di kawasan Kuta-Bali terdeteksi mengandung senyawa halusinogen psilosin. Metode ekstraksi menggunakan SPE dengan pelarut metanol terbukti dapat digunakan dengan optimal dalam analisis senyawa halusinogen yang terkandung pada Magic Mushroom. 
Tabel 1. menunjukkan hasil analisis komposisi kimia senyawa penyusun minuman Magic Mushroom menggunakan GC-MS.

Tabel 1. Senyawa dalam kromatogram minuman Magic Mushroom

\begin{tabular}{|c|c|c|c|}
\hline $\begin{array}{l}\text { Pun- } \\
\text { cak }\end{array}$ & $\begin{array}{l}\text { Waktu } \\
\text { Retensi } \\
\text { (menit) }\end{array}$ & $\begin{array}{c}\text { Kelimpa } \\
\text {-han } \\
(\%)\end{array}$ & Senyawa \\
\hline 1 & 21.08 & 80.53 & Psilosin \\
\hline 2 & 21.50 & 6.11 & Psilosin \\
\hline 3 & 21.88 & 13.29 & $\begin{array}{c}\text { Asam } \\
\text { oktadekadionik }\end{array}$ \\
\hline
\end{tabular}

Psilosin dalam Tabel 1 dapat juga dikonversi dari Psilosibin di dalam hati yang kemudian dieksresikan bersama urin, atau lebih jauh dikonversi menjadi berbagai metabolit psilosin seperti digambarkan dalam Gambar 3 (Passie, et al., 2002).

Magic mushroom bersifat psikoaktif, yaitu suatu bahan yang mengandung zat yang bekerja secara selektif terutama pada otak sehingga dapat menimbulkan perubahan perilaku, emosi, persepsi dan kesadaran sistem saraf otak (Matsushima, et al., 1991). Kandungan pada magic mushroom ditemukan memiliki kesamaan struktural dengan neurotransmitter serotonin, sehingga memiliki potensi halusinogen yang sangat tinggi (Passie et $a l, 2002)$.

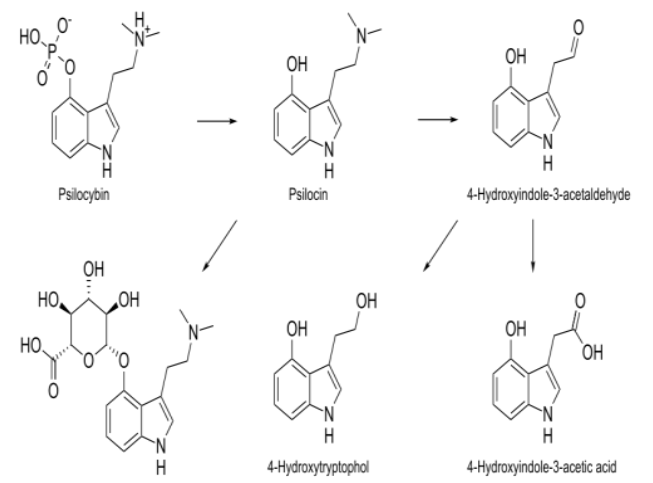

Psilocin O-glucuronide

Gambar 3 Berbagai metabolit psilosisbin yang dieksresikan bersama urin (Passie, et al., 2002)

Berdasarkan reaksi tersebut psilocybin yang terkandung dalam magic mushroom dimetabolisme menjadi psilocin melalui proses defosforilasi. Psilocin mengalami deaminasi untuk menghasilkan asam 4-hydroxyindoleacetic, dan juga membentuk glukuronida oleh reaksi dengan asam glukuronat pada gugus 4hidroksi pada molekul psilocin (Hacket et al, 2011).

Kelimpahan Psilosin sekitar 80\% pada waktu retensi 21,08 menit menandakan konsentrasi paling tinggi terkandung dalam magic mushroom. Hal ini telah dilaporkan oleh Leung dan Paul bahwa selain psilosin juga ada senyawa baeosistin dan norbaeosistin dalam ekstrak magic mushroom yang dianalisis dengan HPLC. Dilaporkan pula bahwa konsentrasi masing-masing senyawa kimia psikoaktif yang terkandung dalam Psilocybe baeocystis adalah 0,15-0,85\% psilosibin, 0,59\% psilosin, dan 0,10 $\%$ baeosistin (Beug dan Bigwood, 1981).

\section{SIMPULAN DAN SARAN}

\section{Simpulan}

Hasil penelitian menunjukkan bahwa metode ekstraksi menggunakan SPE dengan pelarut metanol dapat digunakan secara optimal untuk analisis senyawa halusinogen dalam minuman Magic Mushroom. Terdeteksi senyawa halusinogen di dalam sampel Magic Mushroom dan minuman Magic Mushroom yaitu psilosin dengan waktu retensi terdeteksi pada sampel sesuai dengan NIST02 Database yaitu pada 21.08 menit dengan kelimpahan 80,53\%.

\section{Saran}

Agar lebih meningkatkan upaya sampling, diantaranya meliputi jumlah dan variasi spesies Magic Mushroom yang akan dianalisis agar didapat data lebih spesifik. Perlu dilakukan pengkajian lebih lanjut mengenai metode ekstraksi lainnya agar didapat perbandingan yang lebih akurat mengenai efisiensi hasil analisis.

\section{UCAPAN TERIMA KASIH}

Penulis mengucapkan terima kasih kepada Dra. Ni Made Puspawati, M.Phil. Ph.D, Dr. I Nengah Wirajana, S.Si., M.Si., Ni Komang 
Ariati, S.Si., M.P. atas bimbingan dan koreksinya dalam penyusunan jurnal ilmiah ini. Kepala beserta staff Lab. Forensik POLRI Cabang Denpasar atas fasilitas laboratorium yang diberikan; serta semua pihak yang telah membantu penelitian ini.

\section{DAFTAR PUSTAKA}

Albert, A. Elian., Jeffrey, Hackett., Michael, J. Telepchak., 2011, Analysis of Psilocybin and Psilocin in Urine Using SPE and LC-Tandem Mass Spectrometry, Lcgc North America, 9 (9).

Barry, Massey, 2005, "Growing hallucinogenic mushrooms not illegal, state appeals court rules". Free New Mexican. Santa $\mathrm{Fe}$ New Mexican. Archived from the original on 1 July 2006.

Beug, W., \& Bigwood, J., 1981, Variation Of Psilocybin And Psilocin Levels With Repeated Flushes (Harvests) Of Mature Sporocarps Of Psilocybe Cubensis (Earle) Singer, Journal of Ethnopharmacology 5, Washington.

Hacket, Jeffrey, Albert A. Elian, Michael J. Telepchak, 2011, LCGC North America 29 (9) : 854 - 859

Hofmann, Albert., 1958, LSD: My Problem Child - Chapter 6.2: Psilocybin and Psilocyn.(http://www.maps.org/books/m pc/chapter6.html) diakses pada 27 September 2013 pukul 19.45 WITA.

Leary, Timothy. 2000. The Psychedelic Experience: A Manual Based on the Tibetan Book of the Dead (Citadel Underground). Citadel.

Leung, A.Y., Paul, A.G., 1968, Baeocystin and Norbaeocystin: New Analogs of Psilocybin from Psilocybe baeocystis. Journal of Pharmaceutical Sciences 57 (10): 1667-1671 di akses pada 29 September 2013 pukul 14.33 WITA.

Matsushima Y, Eguchi F, Kikukawa T, Matsuda T, 2009, "Historical overview of psychoactive mushrooms". Inflammation and Regeneration 29 (1): 4758.

Passie, Torsten, Juergen Seifert, Udo Schneider, Hinderk M. Emrich, 2002, The Pharmacology of psilocybin, $J$. Addiction Biologi 7 : 357-354

Tiscione, Nicholas B., Miller, Mattheu, 2006, Psilocin Identified in a DUID Investigation, Journal of Analytical Toxicology, 30, Florida Department of Law Enforcement 